\title{
Sistem Pertanggungan Pada Penjaminan Bancassurance oleh Asuransi X Syariah Menurut Konsep Kafālah.
}

\author{
Nuraiza Zahara \\ Universitas Islam Negeri Sunan Kalijaga, Yogyakarta, Indonesia. \\ nuraizazahara35@gmail.com
}

\begin{abstract}
Cooperation agreement between the Bank and Insurance in the form of a bancassurance system the Bank transfers part of the risk that will arise to the Insurance. Such as the risk of debtor customer financing bottlenecks due to death, the risk borne by the Bank is transferred to the insurance company with life insurance coverage. Insurance agreement for debtor customers, Insurance applies a system based on the kafälah concept. This study explores how the insurance system between the customer and the Bank with the involvement of Insurance as a guarantor in the Bancassurance agreement and how the Islamic legal review of the insurance system carried out by the Insurance against the Bank with the Bancassurance agreement. This research uses descriptive analysis method, which describes or gives a description of the object under study through data or samples that have been collected. The conclusion of the research is that the coverage applied by the Insurance against the Bank is not in accordance with the true kafallah concept, the Insurance has paid the principal fund fully but does not pay the service fee in accordance with the minimum amount determined by the Bank. Based on the concept of insurance, the insurance should be obliged to fulfill everything that is the responsibility of the customer to the Bank, including compensation for services as stipulated. From the explanation above, the concept of kafälah applied by Insurance in its coverage of the Bank is still a mismatch between the concept and its application.
\end{abstract}

Keywords: Insurance, Bancassurance, Kafalah concept.

\begin{abstract}
Abstrak
Perjanjian kerjasama antara Bank dengan Asuransi dalam bentuk sistem bancassurance pihak Bank mengalihkan sebagian risiko yang akan muncul kepada pihak Asuransi. Seperti risiko kemacetan pembiayaan nasabah debitur disebabkan meninggal dunia, maka risiko yang ditanggung oleh Bank dialihkan kepada perusahaan Asuransi dengan pertanggungan asuransi jiwa. Perjanjian pertanggungan terhadap nasabah debitur, Asuransi menerapkan sistem berdasarkan konsep kafälah. Penelitian ini menelusuri bagaimana bentuk sistem pertanggungan antara nasabah dan Bank dengan keterlibatan Asuransi sebagai penanggung dalam perjanjian Bancassurance dan bagaimana tinjauan hukum Islam terhadap sistem pertanggungan yang dilakukan oleh Asuransi terhadap Bank dengan perjanjian Bancassurance. Penelitian ini menggunakan metode deskriptif analisis, yaitu mendeskripsikan atau memberi gambaran terhadap objek yang diteliti melalui data atau sampel yang telah terkumpul. Kesimpulan penelitian bahwa pertanggungan yang diterapkan oleh Asuransi terhadap Bank tidak sesuai dengan konsep kafälah yang sesungguhnya, Asuransi telah melunasi dana pokok sepenuhnya tetapi tidak melunasi imbalan jasa sesuai dengan jumlah minimal yang telah ditetapkan oleh pihak Bank. Ditinjau berdasarkan
\end{abstract}


konsep kafälah asuransi seharusnya wajib menunaikan segala yang menjadi tanggung jawab nasabah terhadap Bank termasuk imbalan jasa sebagaimana ketetapannya. Dari paparan diatas, konsep kafälah yang diterapkan oleh Asuransi dalam pertanggungannya terhadap Bank masih terdapat ketidaksesuaian antara konsep dan penerapannya.

Kata kunci: Pertanggungan, Bancassurance, Konsep kafälah.

\section{PENDAHULUAN}

Setiap perbankan melakukan kerjasama dengan perusahaan asuransi untuk memudahkan pemasaran produk yang dimiliki perusahaan asuransi sekaligus untuk menjamin kepentingan bank dalam melakukan pertanggungan risiko yang muncul dalam pembiayaan. Kerjasama yang terjalin antara perusahaan asuransi dengan perbankan dalam memasarkan produk dikenal dengan bancassurance. Lazimnya perjanjian yang dilakukan antara bank dengan perusahaan asuransi karena kepentingan kedua belah pihak sehingga dalam pemasaran bersama ini pihak asuransi dengan pihak bank melakukan penggabungan produk asuransi dan bank yang bertujuan untuk mempermudah perbankan dan asuransi dalam memasarkan berbagai produk. Dengan system bancassurance ini pihak bank dan perusahaan asuransi menjalin kerjasama yang bersifat simbiosis mutualisme antar kedua institusi berbeda ini. Lazimnya pemasaran bersama dalam bentuk bancassurance ini muncul karena pihak bank lebih dahulu dihubungi oleh costumernya yaitu nasabah debitur yang membutuhkan pembiayaan sudah mempunyai kepercayaan dari masyarakat dalam berbagai masalah lainnya yang berkaitan dengan keuangan. Bank sebelum menyalurkan pembiayaan harus mampu menganalisis kemampuan nasabah debitur demi untuk memastikan bahwa nasabah debitur layak dan dianggap mampu memenuhi kewajibannya kepada bank dengan menggunakan konsep 5C. Konsep 5C ini merupakan prosedur yang harus ditempuh oleh bank sebagai langkah kehati-hatian yang dikenal dengan istilah prudential banking system. 5C ini merupakan singkatan dari Capasity (kemampuan mengembalikan utang), Collateral (jaminan), capital (modal), character (karakter), condition (situasi dan kondisi) (Ismail, 2010).

Meskipun hal ini telah dilakukan pihak bank tetap membutuhkan jaminan lainnya untuk menjamin kepentingan bank dapat terproteksi dengan baik, sehingga pihak bank bekerjasama dengan perusahaan asuransi yang memiliki produk asuransi yang sesuai dengan kepentingan pihak perbankan. Dengan adanya perjanjian kerja sama antara bank dengan perusahaan asuransi dalam bentuk sistem bancassurance pihak bank mengalihkan sebagian risiko yang akan muncul kepada pihak asuransi. Misalnya pihak bank menanggung risiko kemacetan pembiayaan nasabah debitur disebabkan meninggal dunia, maka risiko 
yang ditanggung oleh bank ini dialihkan kepada perusahaan asuransi dengan pertanggungan asuransi jiwa. Misalnya bank mengalami masalah tunggakan nasabah debitur disebabkan meninggal nasabah debiturnya, maka pihak bank hanya menunggu proses klaim yang telah diajukan oleh bank Muamalah Indonesia (BMI) untuk pencairan dana yang macet disebabkan meninggal dunia tersebut kepada perusahaan asuransi yang telah diajak bekerja sama oleh bank syariah.

Bancassurance merupakan sistem yang lebih tepat untuk memberikan jaminan kepada nasabah yang melakukan pembiayaan di Bank Y. Kegiatan operasional yang dilakukan oleh Bank Y dapat dibagi menjadi tiga bagian besar, yaitu : penghimpunan dana, penyaluran dana, dan jasa perbankan. Dalam hal bancassurance maka pihak asuransi menggunakan jasa perbankan dalam menyebarluaskan produknya yang mana dalam fiqh muamalah disebut dengan kafälah (pertanggungan).

Perkembangan produk pada bank bervariasi, dimana bank semakin mampu menawarkan banyak ragam produk. Setiap bank tentunya bekerjasama dengan proteksi asuransi yang berbeda. Akan tetapi masingmasing memiliki kesamaan, yaitu adanya pertanggungan oleh sekolompok orang untuk menolong orang lain yang berada dalam kesulitan (wirdayanigsih Dkk, 2005). Dalam hal ini bukan hanya bank yang membutuhkan asuransi, tetapi juga perusahaan asuransi yang menggunakan jasa bank dalam menginvestasikan dana premi yang diperoleh dari nasabah.

Perusahaan asuransi merupakan lembaga non bank yang bergerak di bidang pertanggungan risiko. Perusahaan asuransi yang ada di Indonesia terbagi menjadi dua, yaitu asuransi konvensional dan asuransi syariah. Adapun pengertian asuransi menurut Kitab Undang-Undang Hukum Perniagaan ayat 246 adalah sebagai berikut:

"Asuransi atau pertanggungan merupakan suatu persetujuan antara dua pihak yaitu pihak penanggung (assurandeur) akan mengganti kerugian pada tertanggung bila terjadi suatu peristiwa tertentu, sebaliknya pihak tertanggung akan membayar suatu jumlah yang dinamakan premi kepada pihak penanggungan" (Thamrin Abdullah dan Francis Tantri, 2013).

Permintaan asuransi muncul karena pada umumnya manusia bersifat risk averse (tidak suka risiko), sehingga mereka memiliki insentif untuk mentransfer risiko. Mereka lebih suka membayar sejumlah dana (premi asuransi) dari pada harus menerima risiko meninggal dunia, kehilangan rumah, mobil, atau lainnya yang menurunkan kekayaan mereka. Tujuan orang membeli asuransi adalah untuk memperoleh perlindungan bila terjadi risiko (Ktut silvanita, 2009). Secara umum yang dimaksudkan dengan risiko adalah setiap kali orang tidak dapat menguasai dengan sempurna, atau mengetahui lebih dahulu mengenai 
masa yang akan datang. Antara asuransi dan risiko mempunyai keterkaitan yang sangat erat, sebab asuransi adalah menanggulangi risiko. Tanpa adanya risiko, asuransi/pertanggungan tidak akan ada (Suhrawardi K. Lubis dan Farid Wajdi, 2018).

Salah satu perusahaan asuransi yang bekerjasama dengan Bank Y Syariah adalah Asuransi $X$ Syariah. Kerjasama antara bank dan perusahaan asuransi dalam bancassurance berbagai variasi, sesuai dengan kebutuhan peserta. Tentunya prinsip kebutuhan ini menjadi salah satu dasar kebolehan asuransi asalkan pada transaksinya tidak mengandung gharar (ketidakjelasan). Secara umum terdapat tiga kelompok, yakni perjanjian pemasaran, pola kerja yang sama dan kelompok jasa keuangan. Dimana kerjasama mengintegrasikan operasi antar bank di depan dan asuransi di belakang dalam rangka menawarkan berbagai produk asuransi kepada nasabah bank. Dalam pembahasan ini Asuransi X Syariah memberikan penjaminan asuransi jiwa terhadap nasabah debitur Bank $Y$ Syariah. Asuransi jiwa yaitu perjanjian asuransi yang memberikan jasa dalam penanggulangan risiko yang dikaitkan dengan hidup atau meninggalnya seseorang yang dipertanggungkan (Suhrawardi K. Lubis dan Farid Wajdi, 2014).

Dalam hal bancassurance jaminan diberikan terhadap nasabah yang melakukan pembiayaan di Bank Y Syariah dengan penjaminan asuransi jiwa oleh Asuransi $X$ Syariah. Pertanggungan akan dilakukan oleh Asuransi X Syariah terhadap Bank Y Syariah apabila nasabah meninggal dunia sebelum masa pelunasan pembiayaan dengan bank selesai. Apabila nasabah debitur meninggal dunia, maka pihak asuransi yang akan membayar dan melunaskan pembiayaan nasabah dengan bank. Pembayaran premi kepada asuransi dilakukan oleh nasabah debitur hanya sekali pada awalnya saja, jumlah premi yang dibayarkan sesuai dengan ketentuan jumlah dana pembiayaan yang diberikan oleh bank kepada nasabah. Pertanggungan yang dilakukan oleh Asuransi X Syariah kepada Bank Y Syariah bersumber dari dana premi nasabah. Pertanggungan tersebut muncul karena adanya kesepakatan kedua belah pihak antara Bank Y Syariah dan Asuransi X Syariah, Bank Y Syariah menyediakan pembiayaan terhadap nasabah debitur dan asuransi memberikan pertanggungan jiwa terhadap nasabah debitur yang meninggal. Apabila nasabah debitur meninggal dunia maka bank mengajukan klaim ke asuransi kemudian asuransi membayar fee atau melunaskan kredit nasabah ke bank. Pada praktik sekarang fee yang dibayar oleh asuransi ke bank sangat sedikit sehingga pihak bank tidak mempunyai keuntungan yang sama besarnya dengan asuransi, sedangkan fee terbesar diperoleh oleh pihak asuransi. Maka oleh karena itu, jumlah keuntungan pihak asuransi dan pihak bank tidak sama jumlahnya disebabkan karena minimnya jumlah fee yang dibayar oleh pihak asuransi 
Sistem Pertanggungan Pada Penjaminan Bancassurance oleh Asuransi X Syariah Menurut Konsep Kafālah.

ke pihak bank. Seharusnya Bank dan asuransi apabila mendapatkan keuntungan maka jumlah keuntungannya harus sama antara keduanya. Bentuk pertanggungan yang diberikan oleh Asuransi $X$ syariah kepada Bank Y Syariah masih belum ada kejelasan tentang pertanggungan yang dilakukan tersebut sudah memenuhi kriteria syariah atau masih banyak kerancuan dalam praktiknya mengenai konsep syariah.

Melalui penelitian yang diajukan oleh penulis, maka tinjauan kepustakaan (literature review) yang akan dilakukan penelitian adalah "Sistem Pertanggungan Pada Penjaminan Bancassurance oleh Asuransi X Syariah Menurut Konsep kafälah)" Menurut penelusuran yang telah peneliti lakukan, belum ada kajian yang membahas secara mendetail dan lebih spesifik yang mengarah pada tema diatas.

Namun ada beberapa tulisan yang berkaitan dengan judul penelitian yang penulis teliti. Di antara tulisan yang secara tidak langsung berkaitan dengan pertanggungan dan pengajuan klaim tersebut diantaranya adalah: Pertama, skripsi yang ditulis oleh Nurhayati. J.16 Dalam hasil penelitiannya membahas mengenai pertanggungan produk AXA Mandiri yang ditawarkan melalui kerjasama antara Bank Syariah Mandiri dengan perusahaan asuransi AXA Mandiri mengatasnamakan pihak perbankan dan tidak dijamin oleh bank. Di dalam penelitian ini lebih dikhususkan pada sistem perjanjian pertanggungan antara nasabah dan Bank syariah Mandiri serta keterlibatan AXA Mandiri dalam bancassurance, bagaimana sistem pertanggungan Mandiri Rencana Sejahtera Pendidikan Syariah oleh AXA Mandiri yang menggunakan sistem bancassurance menurut hukum islam dan bagaimana tinjauan hukum islam terhadap pengajuan klaim pada Asuransi. Namun demikian penulis akan mencoba membahas yang berhubungan dengan pertanggungan pada pembiayaan bank syariah dengan penjaminan bancassurance.

Kedua, karya ilmiah yang ditulis oleh Mulia Nanda. Di dalam hasil penelitiannya membahas mengenai strategi pemasaran produk Bancassurance syariah pada PT. AXA mandiri financial service Banda Aceh yang pembahasannya menyangkut dengan tata cara pemasaran produk bancassurance. Penelitian yang dilakukan oleh Mulia nanda lebih dikuhususkan untuk mengetahui bagaimana cara pemasaran produk bancassurance syariah.

Ketiga karya ilmiah yang ditulis oleh Nadia Putri. Di dalam hasil penelitiannya membahas mengenai paket MobilKoe Syariah yang merupakan produk Asuransi Bumi putera muda (BUMIDA, 1967) Syariah Aceh yang memberikan manfaat pertanggungan menyeluruh, baik risiko kehilangan, kecelakaan pada mobil maupun pemilik kendaraan. Penelitian yang dilakukan Nadia Putri lebih dikhususkan untuk mengetahui bagaimana identifikasi pertanggungan risiko akibat kecelakaan dan kecurian paket MobilKoe Syariah, serta pembuktian yang 
dilakukan peserta untuk mendapatkan klaim sebagaimana disepakati dalam akad. Atas dasar tinjauan kepustakaan tersebut maka ini menjadi peluang untuk melakukan penelitian masih terbuka lebar, tujuannya untuk memahami bagaimana implementasi pertanggungan yang dilakukan oleh Asuransi terhadap Bank dengan menggunakan konsep kafalah.

\section{METODE PENELITIAN}

Penelitian ini menggunakan metode penelitian deskriptif analisis yaitu penelitian terhadap fakta-fakta yang ada saat sekarang dan melaporkannya seperti apa yang terjadi (Marzuki Abu Bakar, 2013). Kemudian dianalisa untuk memperoleh jawaban terhadap masalah tersebut. penelitian ini penulis menggunakan penelitian berdasarkan tinjauan pustaka (Library Research), dan penelittian lapangan (Field Research) mengenai sistem pertanggungan pada penjaminan bancassurance oleh Asuransi X Syariah terhadap Bank Y Syariah yang bersifat deskriptif analisis, yaitu metode pengumpulan data melalui analisa tentang sitem pertanggungan yang dilakukan oleh Asuransi X Syariah terhadap Bank Y syariah.

\section{PEMBAHASAN}

\section{Sistem Pertanggungan Asuransi $X$ Syariah Pada Penjaminan Bancassurance}

Asuransi akan melakukan pertanggungan apabila nasabah debitur meninggal dunia. Utang nasabah debitur menjadi tanggung jawab Asuransi atas pelunasannya apabila nasabah debitur meninggal dunia dikarenakan Bank telah terlebih dahulu membuat perjanjian kerjasama dengan asuransi. Nasabah debitur dibebankan premi untuk asuransi sebagai jaminan apabila meninggal dunia maka asuransi yang akan melunasi sisa hutang nasabah dengan bank. Nasabah debitur ketika mengambil kredit di bank, maka oleh bank secara langsung mengasuransikan jiwa nasabah debitur demi meminimalisir kredit macet terhadap bank apabila nasabah debitur meninggal dunia. Praktik seperti ini dalam Hukum Islam disebut Kafälah. yang mana mengalihkan tanggung jawab seseorang yang dijamin dengan berpegang pada tanggung jawab orang lain sebagai penjamin. Berikut skema Kafālah: 
Sistem Pertanggungan Pada Penjaminan Bancassurance oleh Asuransi X Syariah Menurut Konsep Kafālah.

Gambar 1. Mekanisme akad kafālah

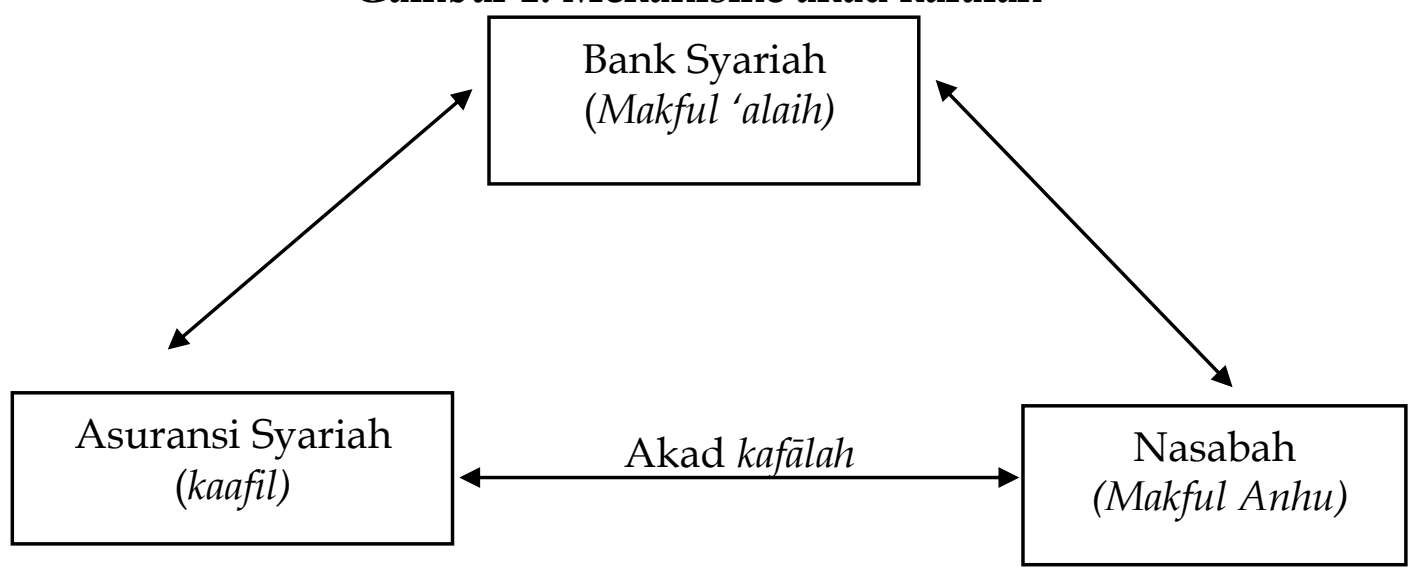

Dari skema di atas dapat dipahami bahwa akad kafālah muncul karena pihak nasabah debitur tidak mampu melunasi kredit nya ke bank dikarenakan meninggal dunia. Asuransi yang menjamin atas pelunasan hutang tersebut terhadap Bank. Maka oleh karena itu, terjadilah akad kafälah antara asuransi, Bank, dan Nasabah. Karena nasabah telah mengalihkan tanggungan nya kepada pihak Asuransi.

Pertanggungan yang menjadi tanggung jawab Asuransi adalah sesuai dengan tarif kontribusi yang telah ditetapkan oleh PT Asuransi X untuk Asuransi Jiwa. Sebagaimana ketetapannya tercantum sebagai berikut:

Tabel 1

Tarip Kontribusi PER 1000 Uang Pertanggungan

\begin{tabular}{c|c|c|c}
\hline \multirow{2}{*}{$\begin{array}{c}\text { MASA } \\
\text { ASURANSI }\end{array}$} & \multicolumn{3}{|c}{ TARIP KONTRIBUSI (PROMIL) } \\
\cline { 2 - 4 } & PNS & BUMN/BUMD/SWASTA & INTERNAL \\
\hline 1 & 3.40 & 4.00 & 3.00 \\
\hline 2 & 6.80 & 8.00 & 6.00 \\
\hline 3 & 10.25 & 11.50 & 9.00 \\
\hline 4 & 14.00 & 15.50 & 12.50 \\
\hline 5 & 17.25 & 20.50 & 15.50 \\
\hline 6 & 20.50 & 25.00 & 21.50 \\
\hline 7 & 24.00 & 27.00 & 24.50 \\
\hline 8 & 27.50 & 30.00 & \\
\hline
\end{tabular}




\begin{tabular}{c|c|c|c}
\hline 9 & 31.25 & 34.00 & 28.00 \\
\hline 10 & 34.85 & 37.50 & 31.00 \\
\hline 11 & 37.80 & 42.00 & 33.50 \\
\hline 12 & 40.85 & 46.00 & 36.50 \\
\hline 13 & 43.80 & 50.00 & 41.00 \\
\hline 14 & 46.70 & 53.00 & 45.50 \\
\hline 15 & 50.00 & 55.00 & 49.00
\end{tabular}

Sumber: Buku Perjanjian Kerjasama Asuransi dan Bank

Tabel di atas memuat tentang perhitungan tahun dan hitungan persen premi yang akan dibayar oleh nasabah debitur. Dari premi tersebut barulah mucul jumlah fee yang akan menjadi milik asuransi dan juga fee yang akan diserahkan oleh Asuransi ke Bank. Misalnya : seorang PNS menjadi nasabah debitur dengan jumlah pembiyaan Rp. 200.000.000 dengan jangka waktu kredit adalah 10 tahun, maka sesuai tabel di atas dengan di bagi 1000 atau permil, premi yang harus dibayar oleh nasabah debitur yaitu sebesar Rp. 6.970.000. Premi tersebut $40 \%$ akan menjadi biaya operasional dalam kondisi ada klaim maupun tidak adanya klaim. Jika tidak adanya klaim, maka dana premi tersebut akan menjadi milik asuransi sepenuhnya tanpa pengembalian persen kepada pihak nasabah debitur. Dalam istilah asuransi dana preminya dimasukkan dalam dana tabarru'.

Apabila nasabah debitur meninggal dunia dan terjadinya klaim, maka pihak asuransi akan melunasi kredit nasabah di bank dengan jumlah fee yang dibayarkan sebesar 5\% ke bank, dan fee 15\% untuk asuransi dan selebihnya $40 \%$ lagi akan masuk ke dalam dana tabarru'. Seharusnya jumlah fee yang diterima oleh bank harus sama jumlahnya dengan fee yang diterima oleh pihak asuransi. Sebagaimana kesepakatannya adalah segala sesuatu yang menjadi tanggungan nasabah akan menjadi tanggungan asuransi, termasuk jumlah fee. Karena apabila nasabah debitur tidak meninggal dunia dan kredit tidak macet, maka fee yang akan diperoleh oleh bank sebesar 10\% dari jumlah pembiayaan yang diambil oleh nasabah.

\section{Prosedur Pengajuan Klaim terhadap Nasabah Debitur}

Klaim adalah hak peserta Asuransi yang wajib diberikan oleh perusahaan asuransi sesuai dengan kesepakatan dalam akad (Tim Penulis Dewan Syarieeah Nasional Majelis Ulama Indonesia). Apabila nasabah 
debitur meninggal dunia maka ahli waris nasabah debitur diharuskan untuk segera melaporkan kepada pihak bank dengan jangka waktu 10 hari dari kematiannya, karena pihak bank sebagai peserta asuransi agar segera bisa melaporkan kepada pihak Asuransi. Ahli waris ketika melapor ke bank harus melampirkan surat keterangan kematian, fotocopy kartu keluarga, fotpcopy KTP, dan surat keterangan ahli waris. Dalam masa perlindungan asuransi syariah pihak Bank Aceh Syariah terhadap permintaan pembayaran pengembalian atas kerugian finansial atau klaim wajib disampaikan kepada pihak Asuransi dengan jangka waktu maksimal 3 Minggu dari hari diterimanya laporan dari ahli waris dengan melengkapi dokumen-dokumen.

Pengajuan permintaan pembayaran klaim untuk resiko meninggal dunia akibat sakit dilengkapi dokumen-dokumen sebagai berikut:

a. Surat keterangan kematian dari pemerintah daerah setempat.

b. Surat keterangan dari Rumah Sakit (apabila meninggal di Rumah Sakit).

c. Foto copy kartu keluarga.

d. Surat keterangan ahli waris yang dilegalisir oleh pemerintah setempat.

e. Surat keterangan dari kedutaan besar Republik Indonesia setempat (apabila meninggal di luar wilayah Republik Indonesia).

Apabila Nasabah debitur meninggal dunia akibat kecelakaan maka Pengajuan permintaan pembayaran klaim harus dilengkapi dokumendokumen sebagai berikut:

a. Surat keterangan kematian dari pemerintah daerah setempat.

b. Foto copy kartu keluarga.

c. Surat keterangan ahli waris yang dilegalisir oleh pemerintah setempat.

d. Surat keterangan kecelakaan dari kepolisian.

e. Putusan pengadilan yang menyatakan peserta meninggal dunia, apabila peserta hilang dalam suatu musibah.

f. Surat keterangan dari kedutaan besar Republik Indonesia setempat (apabila meninggal di luar wilayah Republik Indonesia) (Buku Perjanjian Asuransi dan Bank).

Apabila semua dokumen di atas telah lengkap maka pihak asuransi akan memproses biasanya dalamjangkawaktu 14 hari dan maksimal 1 bulan. Setelah semua proses selesai maka pihak asuransi akan mencairkan dananya dalam jangka waktu minimal 3 bulan dan maksimal 6 bulan.

Berikut skema pengajuan klaim dari Nasabah ke Bank dan dari Bank ke Asuransi: 


\section{Gambar 2. Skema klaim asuransi}

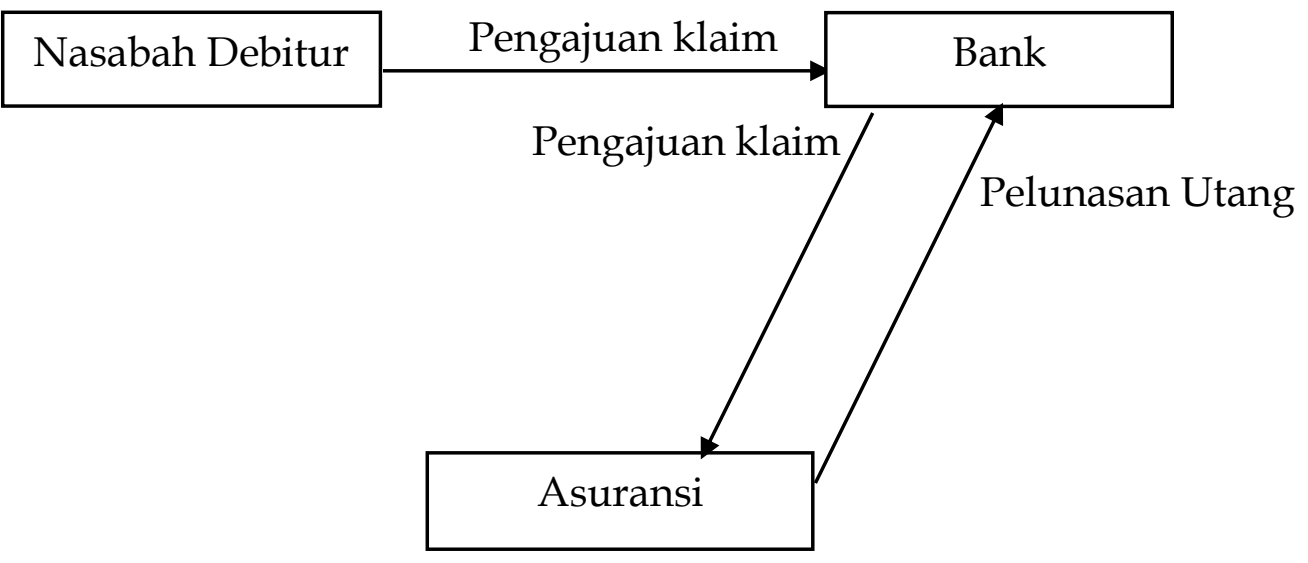

Sumber: Wawancara dengan staf Asuransi X.

Dari skema di atas dapat dipahami bahwa, Asuransi akan mencairkan dana setelah melalui proses klaim mulai Nasabah klaim ke Bank, kemudian Bank mengajukan klaim ke asuransi. Setelah melalui proses tersebut, kemudian Asuransi akan melakukan pelunasan ke Bank atas kredit macet yang disebabkan oleh nasabah debitur yang meninggal dunia.

\section{Analisis Konsep Kafālah terhadap Sistem Pertanggungan Bancassurance oleh Asuransi X Syariah.}

Secara teknis perbankan, kafälah merupakan jasa penjamin nasabah, dimana bank bertindak sebagai penjamin (Kafil), sedangkan nasabah sebagai pihak yang dijamin (makfullah). Apabila nasabah sudah dijamin oleh makfullah maka tanggungan nasabah akan menjadi tanggungan kafil. Prinsip syariah ini sebagai dasar layanan asuransi di bank atau disebut juga dengan Bancassurance (Sunarto Zulkifli, 2003). Dalam hal ini, bank mendapatkan imbalan jasa atau fee yang diberikan. Biasanya penerbitan surat jaminan bank yang salah satunya merupakan jaminan terhadap nasabah debitur yang meninggal dunia diberikan oleh asuransi kepada pihak bank dengan setoran minimal sebesar 10\% dari nilai jaminan yang diinginkan nasabah (Abdul Manan, 2014).

Pertanggungan yang dilakukan oleh Asuransi X Syariah berdasarkan daftar hitungan persen dan jumlah pembiayaan yang diambil dalam jangka waktu tertentu. Pertanggungan dilakukan terhadap kredit macet nasabah debitur dengan menyertakan imbalan jasa atau fee sebesar 5\% untuk Bank dan imbalan jasa untuk asuransi sebesar 15\%. Jumlah pertanggungan imbalan jasa yang diserahkan oleh asuransi belum memenuhi jumlah setoran minimal fee yaitu sebesar 10\%. Jadi, pertanggungan yang dilakukan oleh Asuransi X Syariah belum memenuhi kriteria pertanggungan yang sebenarnya menurut konsep kafälah. 
Segala sesuatu yang menjadi tanggungan nasabah tidak sepenuhnya dijadikan tanggungan asuransi. Seharusnya sebagaimana tercantum dalam perjanjian kerjasamanya adalah apa saja yang menjadi tanggungan nasabah, ketika nasabah meninggal dunia maka akan menjadi tanggungan asuransi sepenuhnya termasuk imbalan jasa tanpa ada pengurangan.

Sebagaimana Hadis dari Jabir bin Abdullah R.A berkata: "Ada seseorang meninggal dunia diantara kami, lalu kami memandikannya, dan memberinya kain kapas, lalu kami kafani, kemudian kami membawanya kepada Rasulullah SAW. Seraya berkata: "Shalatlah untuknya!" Lalu Rasulullah SAW. melangkah untuk mendekat kemudian bertanya, "Apakah dia memiliki tanggungan hutang?" Kami menjawab, "Dua Dinar", lalu Rasulullah SAW. pergi. Maka Abu Qatadah R.A bersedia menanggungnya, lalu kami mendatangi beliau, maka Abu Qatadah R.A berkata, "Saya yang menanggung dua dinar tersebut". Rasulullah SAW. Bersabda,"Bersungguh-sungguhkah engkau mau menanggungnya hingga terlepaslah tanggung jawab mayat tersebut?" Dia menjawab, "Ya", lalu Rasulullah SAW. "Menshalatkannya." (Diriwayatkan oleh Ahmad, Abu Dawud dan an-Nasa'i, dishahihkan oleh Ibnu Hibban dan al-Hakim) (Abdul Qadir Syaibah al-Hamd,2007).

Hadis tersebut menjelaskan tentang utang seseorang yang telah meninggal dunia, yang kemudian ditanggung oleh seorang sahabat, yaitu Abu Qatadah. Abu Qatadah menanggung atas pelunasan tiga dinar hutang orang yang telah meninggal dunia, setelah beliau menanggung baru kemudian dikuburkan jenazah tersebut. Bahwasanya sah saja bagi orang lain untuk menanggung hutang seorang mayit dan melunaskan untuknya dengan syarat tidak boleh mengurangi hitungannya. Apabila hutangnya tiga dinar, maka kewajibannya untuk melunasi tiga dinar tersebut.

Berdasarkan penelitian yang peneliti lakukan pertanggungan yang dilakukan oleh Asuransi X Syariah terhadap Bank Y Syariah apabila ditinjau berdasarkan konsep Kafälah adanya ketidaksesuain antara praktek dan konsep Kafälah. Dalam Kafälah disebutkan bahwa pertanggungan diberikaan oleh penanggung (kafil) kepada pihak ketiga atau yang tertanggung (makful lahu) untuk memenuhi kewajiban pihak kedua (makful ahnu/ashil), segala sesuatu kewajiban pihak kedua akan menjadi kewajiban penanggung terhadap tertanggung (Muhammad, 2014). Namun, berdasarkan penelitian yang peneliti lakukan pihak penanggung tidak sepenuhnya bertanggung jawab atas tanggungan yang akan diberikan kepada pihak tertanggung. Sebagaimana yang dilakukan atas pertanggungan imbalan jasa, pihak asuransi memberikan imbalan jasa kepada pihak bank tidak memenuhi imbalan jasa minimal yang ditetapkan oleh bank. Imbalan jasa minimal yaitu sebesar 10\%, sedangkan pihak asuransi $X$ syariah hanya memberikan sebesar 5\% kepada bank $X$ 
syariah. Sebagaimana pada ayat 72 surah Yusuf Allah SWT. Yang Artinya: "Penyeru-penyeru itu berkata "kami kehilangan piala raja, dan siapa yang dapat mengembalikannya akan memperoleh bahan makanan (seberat) beban unta, dan aku menjamin terhadapnya".

Dalam ayat tersebut dijelaskan bahwa di suatu ketika saudarasaudara Yusuf bertanya "Barang apakah yang hilang dari pada kamu?" Penyeru-penyeru itu berkata, "kami kehilangan piala raja", yakni alat penakar yang biasa digunakan untuk menakar bahan makanan. "Dan siapa yang mengembalikannya akan memperoleh bahan makanan (seberat) beban unta." Hal ini termasuk dari bagian dari bentuk pemberian upah. "Dan aku menjamin terhadapnya." Hal ini merupakan bagian dari bentuk pemberian jaminan (dhiman) dan tanggungan (kafälah) (Abul Fida' 'Imaduddin Isma'il bin Umar bin Katsir al-Qurasyi). Dengan demikian, berdasarkan penjelasan ayat tersebut dapat disimpulkan bahwa apa yang telah menjadi kesepakatan maka wajib untuk ditunaikan kesepakatan tersebut, terutama dalam masalah utang piutang.

\section{KESIMPULAN}

Sistem pertanggungan yang dilakukan oleh Asuransi X Syariah terhadap Bank Y Syariah dengan tertanggungnya nasabah debitur yaitu berdasarkan konsep kafälah, dimana konsep kafälah menjelaskan bahwa pertanggungan diberikan oleh penanggung (kafil) kepada pihak ketiga atau tertanggung (makful lahu) untuk memenuhi kewajiban pihak kedua (makful anhu/ashil), segala sesuatu yang menjadi tanggung jawab nasabah akan menjadi tanggung jawab Asuransi. Dalam hal ini pihak Asuransi berperan sebagai penanggung yang bertanggung jawab atas kewajiban pihak kedua untuk melunasi kredit macet terhadap tertanggung atau pihak Bank.

Berdasarkan tinjauan hukum Islam, pertanggungan dengan melandaskan konsep kafälah hukumnya adalah boleh (mubah). Sebagaimana yang disebutkan dalam hadist "Dari Syurahbil bin Muslim Al-Khaulani dari Abi Umamah berkata: Aku mendengar Rasulullah SAW bersabda dalam khutbahnya pada haji wada': Barang pinjaman itu harus dikembalikan, orang yang menjamin harus membayar jaminannya dan utang itu harus dibayar". (HR. Tirmidzi dan Abu Dawud, dishahihkan oleh Syaikh Al albani dalam silsilah Al-Shahihah). Namun penerapan konsep kafālah dalam pertanggungan ini terdapat ketidak sesuaian antara konsep dan praktiknya. Pihak asurannsi tidak menunaikan sepenuhnya kewajiban nasabah terhadap bank. Asuransi melunasi dana pokok dan imbalan jasa dengan jumlah yang tidak memenuhi jumlah minimal

ketetapan besarnya imbalan jasa yang harus dibayar oleh asuransi untuk bank. Dengan demikian, konsep kafälah yang diterapkan oleh Asuransi X 
Sistem Pertanggungan Pada Penjaminan Bancassurance oleh Asuransi X Syariah Menurut Konsep Kafālah.

Syariah terhadap pertanggungan kepada Bank Y Syariah belum memenuhi kriteria konsep kafälah yang sebenarnya.

\section{DAFTAR PUSTAKA}

Abdullah dan Francis Tantri, Thamrin, Bank dan Lembaga Keuangan, Jakarta: Rajawali Pers, 2013.

Abubakar, Marzuki, Metodologi Penelitian, Banda Aceh, 2013

Fida' 'Imaduddin Isma'il bin Umar bin Katsir al-Qurasyi, Abul, Tafsir Ibnu Katsir, terj. Arif Rahman Hakim, MA. Jawa Tengah: Insan Kamil Solo, 2016.

Ismail, Manajemen Perbankan: Dari Teori Menuju Aplikasi, Jakarta: Kencana, 2010.

Lubis dan Farid Wajdi, Suhrawardi K., Hukum Ekonomi Islam, Jakarta: Sinar Grafika, 2014.

Manan, Abdul, Hukum Ekonomi Syariah dalam Perspektif Kewenangan Peradilan Agama, Jakarta: Kencana PrenadaMedia Group, 2014

Muhammad, Manajemen Dana Bank Syariah, Jakarta: Rajawali Pers, 2014.

Qadir Syaibah al-Hamd, Abdul, Fiqhul Islam: Syarah Bulughul Maram, Jakarta: Darul Haq, 2007.

Silvanita, Ktut, Bank dan Lembaga Keuangan Lainnya, Jakarta: Penerbit Erlangga, 2009.

Tim Penulis Dewan Syari'ah Nasional Majelis Ulama Indonesia, Himpunan Fatwa Dewan Syari'ah Nasional, Jakarta: PT Intermasa

Wirdayaningsih Dkk, Bank dan Asuransi Islam di Indonesia, Jakarta: Kencana, 2005.

Zulkifli, Sunarto, Panduan Praktis Perbankan Syariah, Jakarta Timur: Zikrul Hakim: 2003. 
Halaman ini sengaja dikosongkan 